\title{
Two epizootic diseases in Chesapeake Bay commercial clams, Mya arenaria and Tagelus plebeius
}

\author{
Christopher F. Dungan ${ }^{1, *}$, Rosalee M. Hamilton ${ }^{1}$, Karen L. Hudson ${ }^{2}$, \\ Carol B. McCollough ${ }^{1}$, Kimberly S. Reece ${ }^{2}$
}

${ }^{1}$ Maryland Department of Natural Resources, Cooperative Oxford Laboratory, 904 S. Morris Street, Oxford, Maryland 21654, USA

${ }^{2}$ Virginia Institute of Marine Science, PO Box 1346, Gloucester Point, Virginia 23062, USA

\begin{abstract}
Declining Chesapeake Bay harvests of softshell clams, together with historical and emerging reports of epizootic diseases in Mya arenaria, prompted a survey in summer 2000 of the health status of selected commercial clam populations. All sampled populations ( 8 M. arenaria softshell clam, 2 Tagelus plebeius razor clam) were infected by Perkinsus sp. protozoans at prevalences ranging from 30 to $100 \%$ of sampled clams. Nucleotide sequences for the internal transcribed spacer (ITS) region of the rRNA gene complex were determined for clonal in vitro Perkinsus sp. isolates propagated from both $M$. arenaria and T. plebeius. Multiple polymorphic sequences were amplified from each isolate, but phylogenetic analysis placed all sequences into 2 clades of a monophyletic group, which included both recently described clam parasites $P$. chesapeaki and $P$. andrewsi. Sequences amplified from each clonal isolate were found in both sister clades, one containing $P$. andrewsi and the other $P$. chesapeaki. Most ( 7 of 8) M. arenaria samples were also affected with disseminated neoplasia (DN), at prevalences of 3 to $37 \%$, but neither T. plebeius sample showed DN disease. Disease mortalities projected for sampled clam populations, especially those affected by both diseases, may further deplete subtidal commercial clam populations in mesohaline portions of Chesapeake Bay.
\end{abstract}

KEY WORDS: Mollusc neoplasia - Disseminated neoplasia $\cdot$ Hemic neoplasia $\cdot$ Dermo disease · Perkinsus chesapeaki $\cdot$ Perkinsus andrewsi $\cdot$ Softshell clam $\cdot$ Razor clam

\section{INTRODUCTION}

The softshell clam Mya arenaria has supported an important commercial fishery in the Maryland portion of Chesapeake Bay since the early 1950s, when harvesting of unexploited subtidal populations by hydraulic escalator dredge began. Annual landings of newly exploited stocks peaked at 680000 bu $\left(23960 \mathrm{~m}^{3}\right)$ in 1964, remained above $60 \%$ of peak harvest through 1971, declined to $54-8 \%$ of peak harvest through 1991, and subsequently fell steadily to $2 \%$ of peak landings by 2000 (Maryland DNR Fisheries Service Statistics, Annapolis, Maryland). Although fishing effort has not been estimated for this period, and landings cannot therefore be normalized to effort (catch per

*E-mail: cdungan@dnr.state.md.us unit effort, CPUE), low and consistently falling landings over the past 9 yr suggest that Chesapeake Bay $M$. arenaria populations are in serious decline. As softshell clam catches have fallen, hydraulic clamming dredges have increasingly targeted Tagelus plebeius razor clams, which are marketed as bait for eel and crab pot fisheries.

In addition to fishing mortality and predation, Chesapeake Bay Mya arenaria populations are affected by pathological conditions that may be fatal, including disseminated neoplasia and Perkinsus sp. protozoan infections. Disseminated neoplasia (DN), first described in New England $M$. arenaria (Brown et al. 1977), was subsequently reported as epizootic in some years among Chesapeake Bay $M$. arenaria populations (Farley et al. 1986, 1991). Rapidly proliferating anaplastic and aneuploid cells come to dominate the 
circulatory systems of affected clams, displacing normal hemocyte cells and their critical physiological functions. DN disease pathogenesis has been compared to that of vertebrate leukemia (Smolowitz et al. 1989), and it is fatal within 9 mo of experimental transmission (House et al. 1998). With prevalences of up to $58 \%$ reported in some Chesapeake Bay clam populations (Farley et al. 1991), mortalities from DN disease are estimated to be significant.

Although the etiology and natural transmission mechanisms of DN disease remain unknown, it is mechanically transplantable between affected and healthy Mya arenaria, and is experimentally transmitted through the water column. However, it is not transmitted by injection of healthy clams with cell-free filtrates of affected clam hemolymph, or of filtered hemolymph cell lysates. Despite one report of wholesale DN disease transmission by injection of $0.45 \mu \mathrm{m}$ filtered DN cell lysates into healthy clams (Oprandy et al. 1981), consistent failure by later investigators to transmit the disease with cell-free filtrates has been interpreted as refuting the possibility of a viral agent (McLaughlin et al. 1992). Recent detection of retroviral reverse transcriptase activity in filtrates of tissue homogenates only from DN-affected clams suggests that a retroviral agent is present. However, the failure of reverse transcriptase-positive filtrates to transmit DN disease indicates that the presence of the putative retrovirus alone is insufficient to initiate DN disease (House et al. 1998). Alternatively, in vitro survival of DN cells over $6 \mathrm{~h}$ in a wide variety of physical conditions is interpreted as demonstrating that disseminated DN cells are robust enough to transmit and transplant directly between clams in estuarine environments (Sunila \& Farley 1989). In thorough reviews of occurrences and characteristics of disseminated neoplastic diseases in bivalve molluscs, Tagelus plebeius is not reported as a DN-affected species (Peters 1988, Elston et al. 1992). However, despite a broad distribution which often coincides with that of $M$. arenaria in Chesapeake Bay, few disease investigations have included T. plebeius.

Both Mya arenaria and Tagelus plebeius were reported to be infected by the protozoan oyster pathogen Perkinsus marinus (= Dermocystidium marinum) in a brief, early note (Andrews 1954). However, this parasite was not detected among $2400 \mathrm{M}$. arenaria collected and examined from Chesapeake Bay, Maryland, between 1970 and 1973 (Otto et al. 1979). Since 1990, Perkinsus sp. infections have been detected with apparent increasing frequency among Chesapeake Bay M. arenaria populations (McLaughlin \& Faisal 2000). Analyses of rRNA gene-region nucleotide sequences for 2 Perkinsus sp. isolates propagated from infected M. arenaria confirmed that 1 isolate (H49) was P. mari- nus, but that a second isolate (G117) was not (Kotob et al. 1999b). The second isolate was subsequently described as a new species, $P$. chesapeaki (McLaughlin et al. 2000). Beyond initial reports of 2 distinct Perkinsus sp. in vitro isolates from Chesapeake Bay $M$. arenaria (McLaughlin \& Faisal 1998b), no identification of which agent(s) is(are) implicated in reported recent epizootics is provided (McLaughlin \& Faisal 2000). No previous report describes prevalences or pathology of Perkinsus sp. infections in T. plebeius populations.

Mya arenaria mortalities from Perkinsus sp. infections have not been demonstrated experimentally, and the actual impact of such infections has not been empirically determined. Mild pathology and prevalent defensive parasite encapsulation observed in some infections are interpreted to suggest only that they may compromise growth and reproduction of infected clams (McLaughlin \& Faisal 1998a). However, high parasite densities and systemic distributions shown for other clams indicate an acute, probably lethal, disease condition.

A commercial clam population survey was conducted during late summer 2000 by the Maryland DNR Fisheries Service. The survey estimated health status, abundances, and size structures of commercial Mya arenaria and Tagelus plebeius populations on selected historic subtidal clamming grounds in mesohaline areas of the Maryland portion of Chesapeake Bay. This report details results of disease analyses performed on 8 samples of the softshell clam $M$. arenaria and on 2 samples of the razor clam T. plebeius, collected during the survey.

\section{MATERIALS AND METHODS}

Samples. Samples of Mya arenaria for disease analysis were collected from 2 different sites in each of the following 4 geographically distinct historical softshell clamming areas in the Maryland portion of Chesapeake Bay: Chester River, Upper Bay, Eastern Bay, and Choptank River (Fig. 1). Quantified volumes of bottom sediment were excavated using a commercial hydraulic escalator dredge fitted with a $6.5 \mathrm{~cm}^{2}$-mesh retention screen, and all captured softshell and razor clams were counted. Representative 40-clam $M$. arenaria subsamples were returned in tagged mesh bags to Oxford Laboratory for disease analyses. Representative 40-clam subsamples of Tagelus plebeius for disease analyses were also obtained from 1 arbitrarily selected site in 2 of the 4 geographically distinct clamming areas sampled.

RFTM dermo disease assays. Clam samples were held at the laboratory for 24 to $72 \mathrm{~h}$ in flowing ambient Tred Avon River water to allow clams to purge 
entrained sand. From each sample, 30 live clams were selected and processed for disease analyses. Clams were measured, shucked from their shells, and their muscular mantle margins and siphons trimmed away. The labial palps were excised aseptically, immersed in $3 \mathrm{ml}$ of tubed Ray's fluid thioglycollate medium (RFTM), and incubated at $28^{\circ} \mathrm{C}$ for $96 \mathrm{~h}$ to induce enlargement of Perkinsus sp. parasite cells (Ray 1963, McLaughlin \& Faisal 1999). Incubated labial palp tissues were removed from RFTM, macerated in a small pool of Lugol's iodine solution upon a glass microscope slide, and the resulting stained suspension examined microscopically for enlarged, spherical, blue-black Perkinsus sp. parasite cells. Relative parasite densities in tissue macerates were categorized and recorded as absent (0), or light (1) to heavy (5) (Mackin 1961, Choi et al. 1989). For each clam sample analyzed, a Perkinsus sp. infection-intensity index was calculated as the sum of the categorical infection

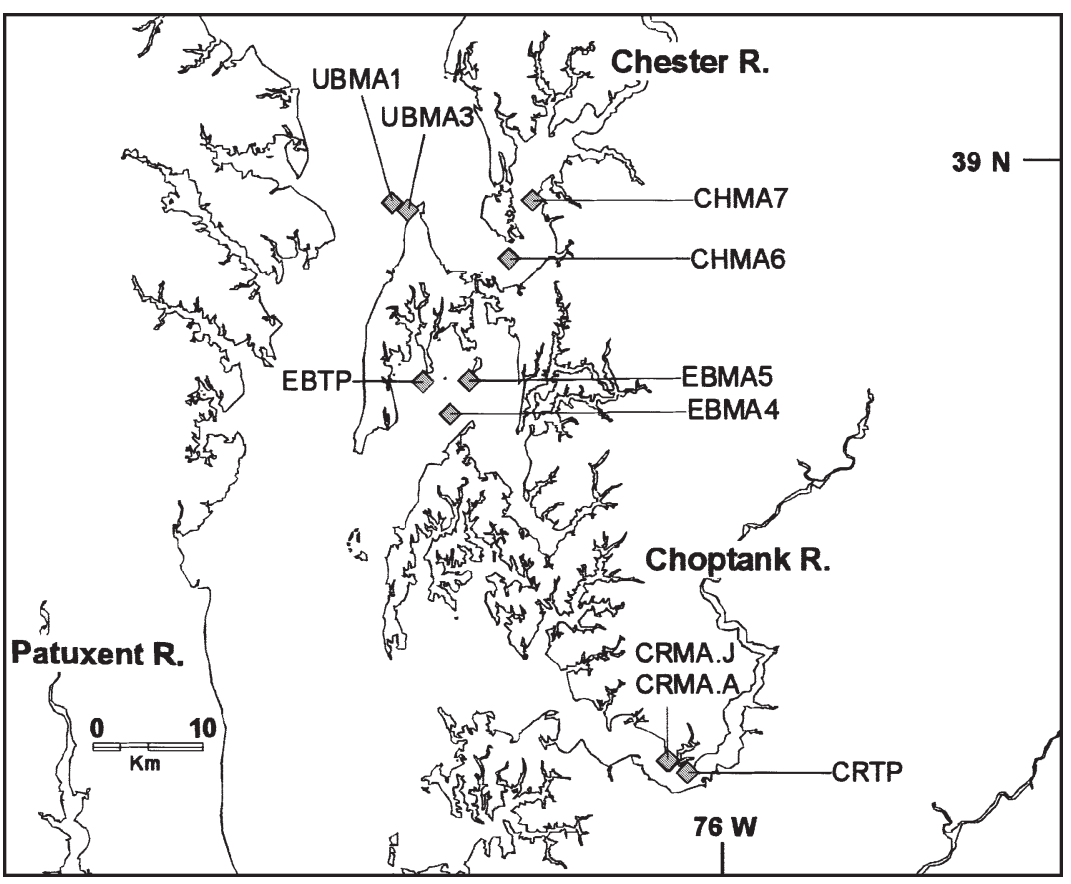

Fig. 1. Sampling sites for Maryland Chesapeake Bay clam disease during Maryland DNR clam survey in August 2000. Sample codes specify source tributary or region (EB: Eastern Bay; UB: Upper Bay; CH: Chester River, CR: Choptank River), sampled clam species (MA: Mya arenaria; TP: Tagelus plebeius), and sampling station number. .J: juvenile; .A: adult intensities of individual infected clams, divided by the number of infected clams in the sample. Sample disease prevalences were calculated as the percent of assayed sample clams affected.

Histopathological analyses. Following labial palp excision, gills were partially freed from their anterior basal attachments to the visceral mass and retracted posteriorly to permit a frontal-transverse bisection of the visceral mass, posterior to the mouth on the dorsal surface and angling posteriorly through the ventral surface of the visceral mass. This first cut bisected stomach, digestive gland, intestine, crystalline style, and gonad. Gills were returned anteriorly to their original position, and the visceral mass was again bisected parallel and posterior to the first cut through Keber's (brown) gland, intestine, kidney, and gills. The resulting (2) posterior tissue masses were placed in a labeled tissue cassette and immediately fixed in Davidson's solution with gentle agitation for $48 \mathrm{~h}$ before dehydration and infiltration. Paraffin-infiltrated tissues were embedded adjacent to each other in the same block, such that sections from the anterior surfaces of both tissue masses were obtained when blocks were sectioned. Tissues were sectioned at 5 to $6 \mu \mathrm{m}$ thickness, stained with Mayer's hematoxylin and eosin, coverslipped, and examined microscopically.

Histological sections were examined for the presence, tissue distribution, and intensity of DN disease, for the presence, distribution, intensity, and hostdefensive response to Perkinsus sp. infections, and for the presence, intensity, tissue distribution, and pathology of other infectious or parasitic conditions. The intensity of DN disease was allocated stages (1 to 5) for affected clams (Farley et al. 1986) and a DN diseaseintensity index was calculated for each clam sample as the sum of the disease-intensity stages of individual affected clams divided by the number of affected clams in the sample.

Immunoassays. Histological fluorescence immunoassays for detection and identification of Perkinsus sp. parasites were performed as described, using protein A-purified rabbit polyclonal IgG antibodies to P. marinus, which label all known Perkinsus species (Dungan \& Roberson 1993, Blackbourn et al. 1998, Bushek et al. 2002). Following dewaxing, rehydration, and blocking, sections were incubated for $1 \mathrm{~h}$ with $10 \mu \mathrm{g} \mathrm{ml}^{-1}$ rabbit anti- $P$. marinus primary IgG antibodies, washed 3 times, and then incubated for $1 \mathrm{~h}$ with $1 \mu \mathrm{g} \mathrm{ml}{ }^{-1}$ of affinity-purified FITC-congugated goat anti-rabbit IgG secondary antibodies. Unbound fluorescein congugate was removed by 3 washes and immunostained sections were counterstained with $0.5 \%$ (w/v) Evan's blue before coverslipping in $\mathrm{pH} 9$ glycerol mounting medium. Positive controls were sections of $P$. marinusinfected Crassostrea virginica oyster tissues. Negative 
controls included replicate test sections which were only dewaxed, blocked, and counterstained to test for autofluorescent sample components, and replicate test sections on which normal rabbit IgG was substituted for the specific primary antibody during immunostaining, to test for nonspecific binding of either primary or secondary antibodies.

Pathogen isolation and propagation. Replicate RFTM-incubated labial palp tissues from several heavily infected clams were separately homogenized with sterile pestles in sterile $1.5 \mathrm{ml}$ microcentrifuge tubes containing $1 \mathrm{ml}$ of serum-free, $900 \mathrm{mOsm} \mathrm{kg}^{-1}$ DME/Ham's F-12 Perkinsus sp. culture medium (Dungan \& Hamilton 1995) supplemented with penicillin $\left(340 \mathrm{U} \mathrm{ml}^{-1}\right)$, streptomycin $\left(340 \mathrm{\mu g} \mathrm{ml}^{-1}\right)$, gentamicin $\left(210 \mathrm{~g} \mathrm{ml}^{-1}\right)$, and nystatin $\left(422 \mathrm{U} \mathrm{ml}^{-1}\right)$ (DME/F12-0). Homogenates were washed through a $70 \mu \mathrm{m}$ pore-size sterile nylon mesh with $10 \mathrm{ml}$ of DME/F12-0, and the cells were pelleted by filtrate centrifugation at $240 \times g$ for $5 \mathrm{~min}$. The supernatant medium was discarded, the cell pellets resuspended in $8 \mathrm{ml}$ of DME/F12 supplemented to $3 \%(\mathrm{v} / \mathrm{v})$ fetal bovine serum (DME/F12-3), and the resulting suspension inoculated $\left(2 \mathrm{ml} \mathrm{well}^{-1}\right)$ into 4 replicate wells of sterile 24 -well culture plates. The edge wells of the culture plates were filled with sterile water for humidity control, and the covered plates were incubated at $28^{\circ} \mathrm{C}$, with daily microscopic observations to monitor Perkinsus sp. proliferation.

Once Perkinsus sp. isolate proliferation was confirmed 4 to $10 \mathrm{~d}$ post-inoculation, proliferating parasite cell cultures were expanded to flasks, nystatin supplements eliminated from the culture medium, and the isolate cell suspensions cryopreserved (Dungan \& Hamilton 1995). At the time of cryopreservation, isolates were also cloned by limiting dilution plating in 96-well culture plates. An aliquot of isolate cells was washed for $3 \mathrm{~min}$ at $240 \times g$ to deplete motile zoospores in the cell pellet. The resulting, nominally non-motile, cell population was enumerated, diluted in DME/F12-3 to an estimated concentration of 5 cells $\mathrm{ml}^{-1}$, and $100 \mu \mathrm{l}$ aliquots of the resulting suspension inoculated into wells containing $100 \mu \mathrm{l}$ of cell-free conditioned medium (Bushek et al. 2000). At 2 and $18 \mathrm{~h}$ post-plating, all wells of cloning plates were exhaustively examined microscopically, and wells containing only a single inoculum cell at both screenings were marked as monoclonal for expansion. Monoclonal cultures proliferated within $4 \mathrm{~d}$ post-inoculation, and 1 clone from each isolate was expanded and cryopreserved.

Pathogen identification. Cloned, viable Perkinsus sp. cells were transferred to the Virginia Institute of Marine Science for identification by comparison of their rRNA gene internal transcribed spacer-region (ITS) nucleotide sequences with those published for other Perkinsus sp. parasites of marine molluscs. Monoclonal cell populations of Perkinsus sp. from Chesapeake Bay clams were propagated in vitro, harvested, washed twice in phosphate-buffered saline (PBS), and resuspended in lysis solution $(50 \mathrm{mM}$ Tris$\mathrm{HCl}, \mathrm{pH}$ 8.0, 100 mM EDTA, 1\% Sarkosyl, $0.5 \mathrm{mg} \mathrm{ml}$ ${ }^{-1}$ proteinase K). Cell suspensions were lysed overnight at $50^{\circ} \mathrm{C}$, particulate fractions removed by centrifugation, and proteins extracted twice from soluble lysate fractions with equal volumes of a phenol: chloroform:isoamyl alcohol (25:24:1) mixture. Genomic DNA was precipitated from the extracted lysate aqueous fraction by the addition of 0.1 vol. $3 \mathrm{M}$ sodium acetate, $\mathrm{pH} 5.2$, and 2 vol. $95 \%$ ethanol. Following precipitation for $2 \mathrm{~h}$ at $-20^{\circ} \mathrm{C}$, DNA was pelleted by centrifugation, air-dried, and then resuspended in $0.1 \times$ TE buffer $(1 \mathrm{mM}$ Tris- $\mathrm{HCl}, \mathrm{pH} 8.0$, $0.1 \mathrm{mM}$ EDTA).

Approximately 50 ng of genomic DNA from Perkinsus sp. isolates were PCR-amplified, using the BRL PCR Reagent System (Life Technologies) and a DNA engine thermocycler (MJ Research). Reagent concentrations for PCR reactions were as follows: $20 \mathrm{mM}$ Tris$\mathrm{HCl}, \mathrm{pH} 8.4,50 \mathrm{mM} \mathrm{KCl}, 1.5 \mathrm{mM} \mathrm{MgCl} 2,0.2 \mathrm{mM}$ each of dATP, dGTP, dCTP and dTTP. Each amplification reaction was catalyzed by 50 pmol of each primer and $1.25 \mathrm{U}$ of Taq DNA polymerase. Universal ITS primers, which amplify the ITS1, ITS2, and 5.8S regions of the rRNA genes of all known Perkinsus species were used (Goggin 1994). Cycling conditions were as follows: initial denaturation of $4 \mathrm{~min}$ at $95^{\circ} \mathrm{C}$, followed by 40 amplification cycles $\left(1 \mathrm{~min}\right.$ at $95^{\circ} \mathrm{C}, 1 \mathrm{~min}$ at $55^{\circ} \mathrm{C}$, 3 min at $65^{\circ} \mathrm{C}$ ), with a final amplicon extension period of $5 \mathrm{~min}$ at $65^{\circ} \mathrm{C}$. The resulting PCR products were verified by agarose gel electrophoresis to be of both homogeneous and expected lengths (750 bp). Amplification products were cloned into the pCR 2.1 vector using the TA Cloning Kit (Invitrogen), following the manufacturer's protocol.

Multiple (8 to 10) replicate cloned PCR amplicon inserts from the ITS region of each Perkinsus species isolate were sequenced by simultaneous, bidirectional cycle sequencing using the Thermo Sequenase kit (Amersham Life Science) and IRD700- and IRD800labeled M13 forward and reverse primers (Li-Cor). Reactions were run on a Li-Cor Model 4200 automated DNA sequencer, nucleotide sequences were aligned using the MacVector software package (Oxford Molecular), and phylogenetic analyses were performed using PAUP 4.0 (Swofford 1999) software. Genetic distance and parsimony analyses were performed to estimate the similarity of aligned ITS sequences from clam Perkinsus sp. isolates to those of both described and undescribed Perkinsus species deposited with GenBank. 


\section{RESULTS}

\section{DN disease}

Of 8 sampled Mya arenaria populations, 7 (88\%) were affected with disseminated neoplasia at prevalences ranging from 3 to $37 \%$ (Table 1). The lone unaffected $M$. arenaria sample was comprised of juvenile $(1+$ yr) clams from the Choptank River. Neoplasia prevalences were lowest among sampled Chester River and Choptank River populations and highest among Eastern Bay and Upper Bay populations. DN disease-intensity indices were lowest among lowprevalence $M$. arenaria populations from the Choptank River, and highest (4.0 of a maximum of 5.0) among low-prevalence populations from the Chester River. High-prevalence (17 to $37 \%$ ) M. arenaria samples from Eastern Bay and Upper Bay regions also had relatively high DN-disease intensity indices approaching or exceeding 2.0. Neither sampled razor clam population was affected with DN disease, despite the fact that the Eastern Bay Tagelus plebeius sample came from the same sampling area whose $M$. arenaria samples showed the highest (33 to $37 \%$ ) DN-disease prevalences.

The cytology of DN-disease neoplastic cells was similar to that described by Farley et al. (1986) and
Peters (1988). Hypertrophied and hyperplastic DN cells contained proportionately large, often bilobed and hyperchromatic nuclei with prominent single or multiple nucleoli (Fig. 2). A small and variable proportion of DN cells was binucleate. The proportion of neoplastic cells circulating in the hemolymph apparently increased with increasing disease intensity, until normal hemocytes were almost completely displaced in advanced cases. High mitotic frequencies and abnormal mitotic figures among DN cells reflected their abnormally high proliferation rate, and aberrant chromosome segregation typical of aneuploidy was frequently observed at karyokinesis (Elston et al. 1992).

\section{Perkinsus sp. infections}

All samples of both clam species harbored Perkinsus sp. infections at prevalences ranging from 30 to $100 \%$ as determined by RFTM assays of labial palp tissues (Table 1). Among tested Mya arenaria samples, those from Eastern Bay populations had both the highest prevalences $(100 \%)$ and the highest infection-intensity indices for infected individuals. Other $M$. arenaria samples from both the Chester and Choptank rivers also showed high infection prevalences (87 and 83\%),

Table 1. Mya arenaria and Tagelus plebeius. Disease assay summary results from samples collected during summer 2000 from Maryland's Chesapeake Bay clamming grounds. Intensity indexes were recorded on a scale from 1 to 5 , where $0=$ absent, $1=$ light $\ldots 5=$ heavy. Sample codes as in Fig. 1

\begin{tabular}{|c|c|c|c|c|c|c|}
\hline \multirow{2}{*}{$\begin{array}{l}\text { Sample code, } \\
\text { (yymmdd) }\end{array}$} & \multirow{2}{*}{$\begin{array}{l}\text { Clam } \\
\text { species }\end{array}$} & \multirow{2}{*}{$\begin{array}{l}\text { Tributary/Region } \\
\text { Site }\end{array}$} & \multicolumn{2}{|c|}{ Perkinsus sp. infection } & \multicolumn{2}{|c|}{ Disseminated neoplasia } \\
\hline & & & $\begin{array}{c}\text { Prevalence }^{\mathrm{a}} \\
(\%)\end{array}$ & $\begin{array}{l}\text { Intensity index } \\
\\
(1-5)\end{array}$ & $\begin{array}{l}\text { Prevalence }^{\mathrm{a}} \\
(\%)\end{array}$ & $\begin{array}{l}\text { Intensity index } \\
\\
(1-5)\end{array}$ \\
\hline $\begin{array}{l}\text { CHMA6 } \\
000901\end{array}$ & M. arenaria & $\begin{array}{l}\text { Chester River, } \\
\text { Cedar Point }\end{array}$ & 87 & 1.7 & 3 & 4.0 \\
\hline $\begin{array}{l}\text { CHMA7 } \\
000901\end{array}$ & M. arenaria & $\begin{array}{l}\text { Chester River, } \\
\text { Piney Point }\end{array}$ & 50 & 1.3 & 7 & 4.0 \\
\hline $\begin{array}{l}\text { UBMA1 } \\
000908\end{array}$ & M. arenaria & $\begin{array}{l}\text { Upper Bay, } \\
\text { W. Kent Island }\end{array}$ & 57 & 1.5 & 27 & 2.9 \\
\hline $\begin{array}{l}\text { UBMA3 } \\
000908\end{array}$ & M. arenaria & $\begin{array}{l}\text { Upper Bay, } \\
\text { W. Love Point }\end{array}$ & 30 & 1.4 & 17 & 3.0 \\
\hline $\begin{array}{l}\text { EBMA4 } \\
000831\end{array}$ & M. arenaria & $\begin{array}{l}\text { Eastern Bay, } \\
\text { Upper Hill }\end{array}$ & 100 & 2.2 & 37 & 1.9 \\
\hline $\begin{array}{l}\text { EBMA5 } \\
000830\end{array}$ & M. arenaria & $\begin{array}{l}\text { Eastern Bay, } \\
\text { Parson's Island }\end{array}$ & 100 & 2.5 & 33 & 2.4 \\
\hline $\begin{array}{l}\text { CRMA.A } \\
000816\end{array}$ & M. arenaria & $\begin{array}{l}\text { Choptank River, } \\
\text { Malkus Bridge }\end{array}$ & 40 & 1.7 & 3 & 1.0 \\
\hline $\begin{array}{l}\text { CRMA.J } \\
000816\end{array}$ & M. arenaria & $\begin{array}{l}\text { Choptank River, } \\
\text { Malkus Bridge }\end{array}$ & 83 & 2.2 & 0 & 0 \\
\hline $\begin{array}{l}\text { EBTP } \\
000817\end{array}$ & T. plebeius & $\begin{array}{l}\text { Eastern Bay, } \\
\text { Turkey Point }\end{array}$ & 100 & 0.8 & 0 & 0 \\
\hline $\begin{array}{l}\text { CRTP } \\
000831\end{array}$ & T. plebeius & $\begin{array}{l}\text { Choptank River, } \\
\text { Bolingbroke Sands }\end{array}$ & 100 & 2.3 & 0 & 0 \\
\hline
\end{tabular}




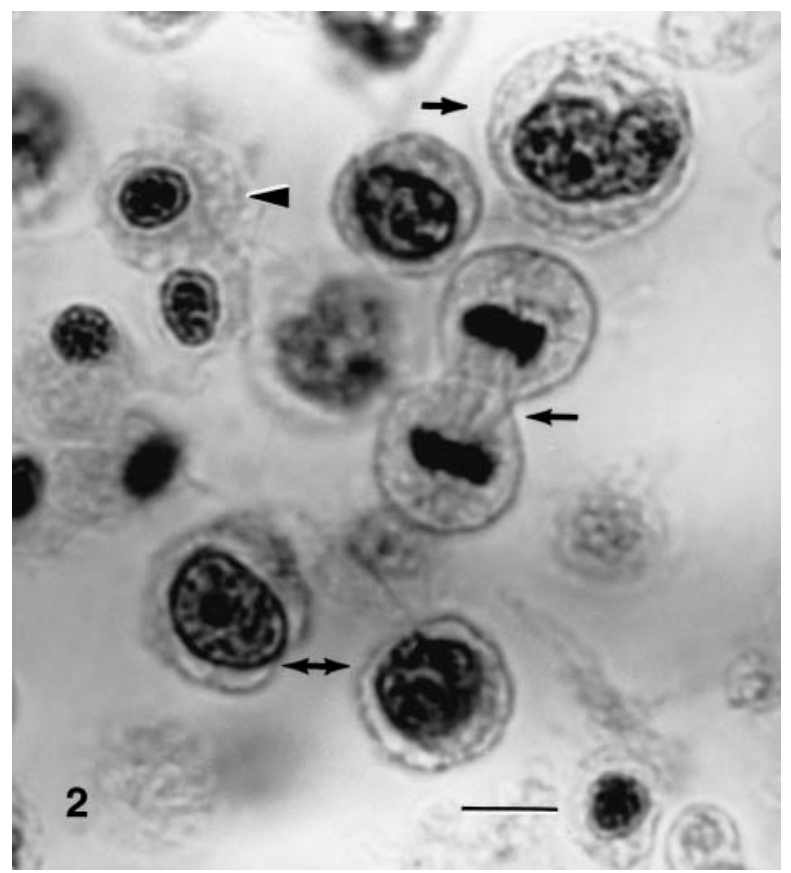

Fig. 2. Mya arenaria. Disseminated neoplasia (DN) cells and normal hemocytes in the gill vein. Smaller hemocytes with heterochromatic nuclei and acidophilic cytoplasm (arrowhead) are contrasted with large DN cells (arrows) with large, often bilobed, nuclei containing prominent nucleoli, and characterized by high mitotic activity. Late telophase mitotic figure shows DN cell chromosome plate, mitotic spindle, and cytokinetic constriction at division plane. Scale bar $=5 \mu \mathrm{m}$

with moderately high infection intensity indices approximating 2.0 of the maximum 5.0. Juvenile $(1+\mathrm{yr})$ and adult $(2+\mathrm{yr})$ M. arenaria dredged from adjacent Choptank River locations (CRMA.J and CRMA.A, respectively: Fig. 1) showed a notably lower infection prevalence $(40 \%)$ in the adult clam sample than in the juvenile clam sample (83\%). This contrast suggests differential, age-dependent infection susceptibility, or may reflect differential mortality of infected clams in older age classes. Both Tagelus plebeius samples showed infection prevalences of $100 \%$ of tested clams, with the Choptank River sample (CRTP) also showing a moderately high infection-intensity index (2.3).

In both clam species, Perkinsus sp. infections were detected histologically in only 6 to $43 \%$ of individuals for which RFTM assays of labial palp tissues were positive for Perkinsus sp. parasites. This disparity in diagnostic assay sensitivity has previously been reported for Mya arenaria (McLaughlin \& Faisal 1999). Gill tissues were the most common site of histologically detected lesions, and were typically also the tissue with the highest parasite densities. In $M$. arenaria, the digestive gland, kidney, gonad, and hemocoel tissues followed, in order of both frequency and intensity, as sites of parasite lesions. In Tagelus plebeius, parasite lesions were found only in gill and labial palp tissues.

As described for Mya arenaria (McLaughlin \& Faisal 1998a), 90 to $100 \%$ of Perkinsus sp. cells observed histologically in both clam species appeared to be either encapsulated or phagocytized by hemocytes, as part of an apparent host-clam defensive response. However, parasite cells in our samples did not appear effectively inhibited, contained, or destroyed by this host response, but instead appeared to proliferate aggressively within typically thin granulomatous encapsulations (Fig. 3), and to disseminate systemically throughout host clam tissues. Typical parasite trophozoites in histological sections were 5 to $20 \mu \mathrm{m}$ in diameter, and had signet-ring morphology with a single large vacuole and an eccentric nucleus with a prominent, acidophilic nucleolus. Proliferation was by internal schizogany of enlarged mother cells to yield approximately 4 to 16 small daughter trophozoites (Figs. $3 \& 4$ ). Similar to immunostaining results for $P$. marinus in positive-control infected-oyster sections (Dungan \& Roberson 1993), cell wall, cytoplasmic, and nuclear epitopes of the Perkinsus sp. parasites of the clams were labeled by anti-P. marinus antibodies (Fig. 4). Although qualitative and quantitative immunostaining variability occurred between parasite cells, cell wall and nuclear epitopes of Perkinsus sp. parasites in tissues from both infected clam species were usually intensely labeled.

Despite the fact that all Perkinsus sp. in vitro isolates from both clam species zoosporulated frequently and continuously, in vivo zoosporulation was never observed histologically among Perkinsus sp. parasites infecting either Муа arenaria or Tagelus plebeius. Unlike the pattern of apparent tropism for the epithelial tissue of the digestive tract exhibited by P. marinus in oysters, Perkinsus sp. lesions in clams predominated in connective tissues, and were rare in epithelia. Frequent high parasite densities in critical clam tissue and organ systems, together with an apparent high rate of parasite proliferation suggest that the observed Perkinsus sp. infections in clams are acute conditions with fatal outcomes.

\section{Parasite isolation}

Vigorous axenic in vitro Perkinsus sp. isolates from both Mya arenaria and Tagelus plebeius were readily propagated, cloned, and cryopreserved by the methods described. Our Perkinsus sp. isolate from $M$. arenaria (CRMA.J-44) was deposited at the American Type Culture Collection as ATCC 50863, and its monoclonal derivative (CRMA.J-44/E3) as ATCC 50864. Our 

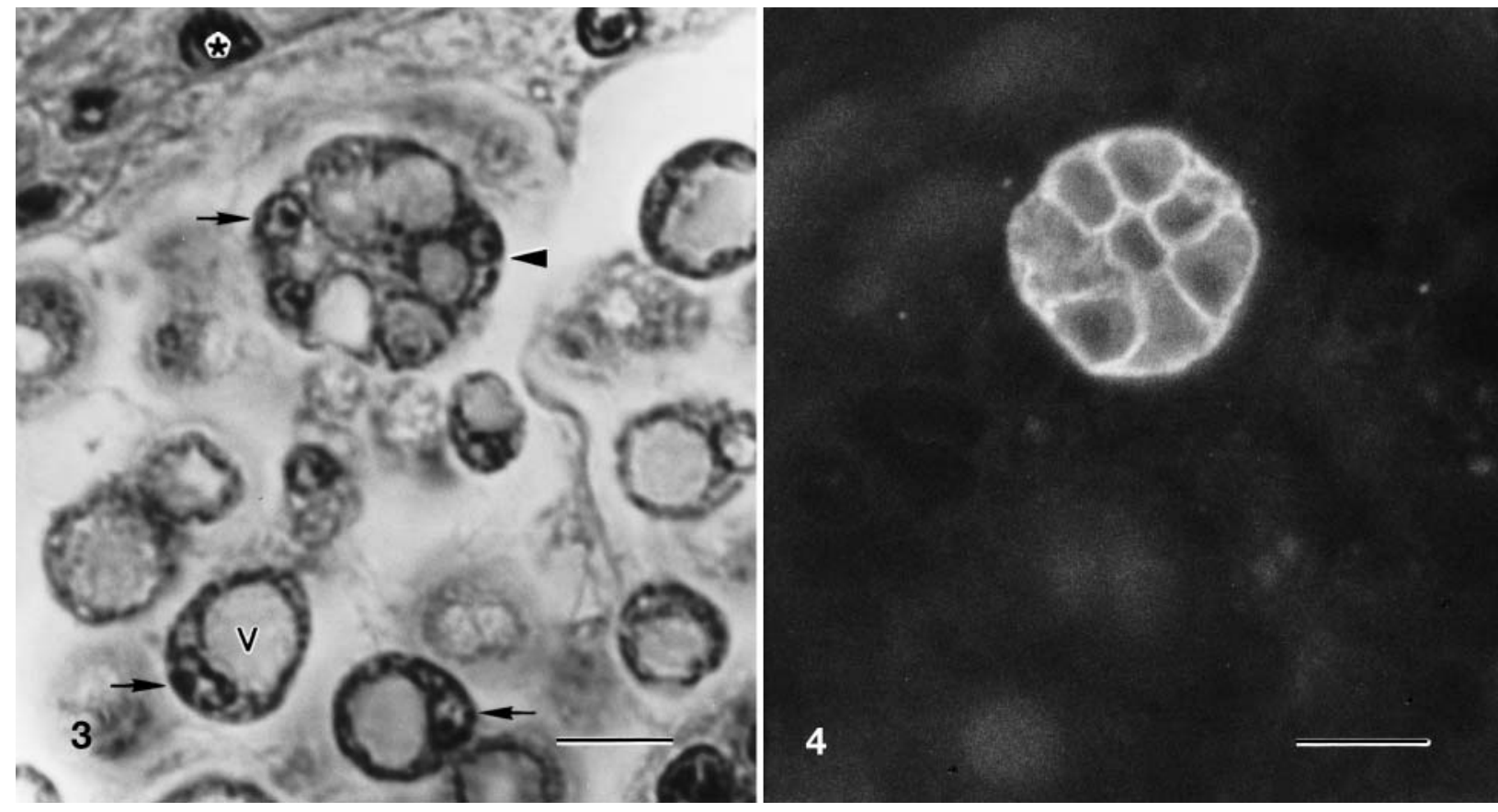

Figs. 3 \& 4. Perkinsus sp. lesions in Mya arenaria gill connective tissues. Fig. 3. Large subdividing Perkinsus sp. schizont (arrowhead) contains approximately 16 small daughter trophozoites with developing vacuoles; numerous trophozoites with large eccentric vacuoles (V) are shown; hypochromatic parasite nuclei with prominent, acidophilic nucleoli (arrows) are contrasted with hetrochromatic host connective tissue cell nuclei (asterisk). Fig. 4. Perkinsus sp. schizont in Mya arenaria gill connective tissue, fluorescence immunostained with antibodies to $P$. marinus; cell membranes forming internally between small daughter trophozoites are intensely labeled, while parasite cytoplasm and nuclei are uncharacteristically lightly stained. Scale bars $=5 \mu \mathrm{m}$

Perkinsus sp. isolate from T. plebeius (CRTP-17) was deposited as ATCC 50865, and its monoclonal derivative (CRTP-17/A10) as ATCC 50866.

Unlike Perkinsus marinus, which propagates exclusively by schizogany after the first in vitro generation (La Peyre 1996), monoclonal parasite cell lines isolated from each clam host displayed 2 concurrent cell cycles through at least 10 generations in culture. Most trophozoite cells propagated by apparent vegetative schizogany, similar to that described for in vitro P. marinus (Sunila et al. 2001). Mother cells enlarged to 10 to $30 \mu \mathrm{m}$ diameter (Fig. 5), apparently replicated their genome multiple times, and then subdivided internally as schizonts to yield clusters of homogeneous, small daughter cells (Fig. 6). Daughter cells subsequently enlarged to repeat the schizogonic cycle, or to zoosporulate.

In both our clam isolates, some subsets of daughter cells produced by schizogany enlarged to diameters of 40 to $90 \mu \mathrm{m}$ and zoosporulated by a process similar to that originally described for Perkinsus marinus (Perkins 1996). Successive internal bipartition of zoosporont sporoplasm yielded progressively smaller zoosporoblast cells (Fig. 7). Zoosporoblasts ultimately developed flagella prior to release through the zoosporangium discharge tube as pyriform, biflagellate, $4.0 \times 2.7 \mu \mathrm{m}$, motile zoospores (Fig. 8).

Limiting dilution clonal subculture of both single zoospore and single trophzoite cells demonstrated that trophozoite cells plated singly into culture wells were immediately able to either zoosporulate or to propagate by schizogany. Zoosporulation by trophozoites appeared to be differentially stimulated by low-density clonal plating, because the zoosporulation frequency in cloning wells was higher (up to $90 \%$ ) than that typically observed in high-density flask cultures (5 to $10 \%$ ). Motile zoospores plated individually into culture wells lost motility over several days and, following an additional 5 d lag period, enlarged to proliferate by either schizogany or zoosporulation. Thus, both trophozoites and zoospores were reciprocally able to proliferate by both in vitro cell cycles, as suggested for Perkinsus marinus (La Peyre \& Faisal 1995) and also documented for P. andrewsi (Coss et al. 2001a).

\section{Parasite identification}

Perkinsus sp. parasite cells in histological sections from both infected Mya arenaria and Tagelus plebeius 

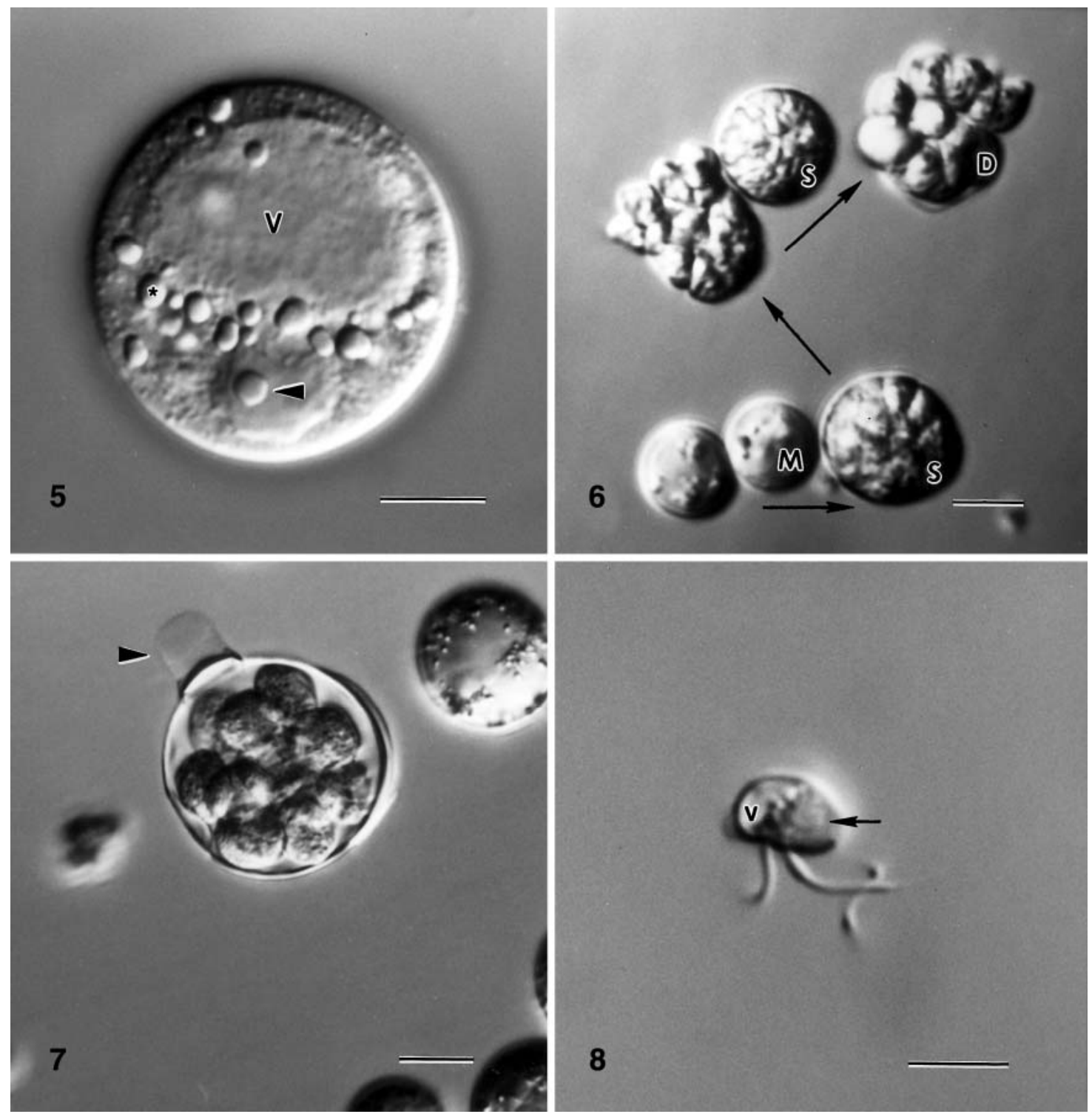

Figs. 5-8. Live in vitro Perkinsus sp. isolate cells (ATCC 50865) propagated from Tagelus plebeius. Fig. 5. Mature trophozoite with eccentric vacuole (V), vacuoplast, and vacuole margins protuberant with large, refractile cytoplasmic granules (asterisk), amorphous nucleoplasm surrounds prominent nucleolus (arrowhead); Nomarski DIC, scale bar $=5 \mu \mathrm{m}$. Fig. 6 . In vitro schizogonic cell cycle; large trophozoites (M) subdivide internally as schizonts (S) to yield many small daughter trophozoites, which lyse the schizont wall and enlarge as daughter cell clusters (D) to repeat the proliferative cycle; Hoffman MC, scale bar $=20 \mu \mathrm{m}$. Fig. 7. In vitro zoosporulation; zoosporont with discharge tube (arrowhead), containing approximately 16 zoosporoblasts in the process of reductive divisions that will yield hundreds of motile zoospores; Hoffman $M C$, scale bar $=20 \mu \mathrm{m}$. Fig. 8. Biflagellated, pyriform, $4 \times 2.7 \mu \mathrm{m}$ zoospore; anterior vacuole (V) and posterior nucleus with nucleolus (arrow) are shown; Nomarski DIC, scale bar $=4 \mu \mathrm{m}$

were labeled by rabbit antibodies to P. marinus (Fig. 4), tentatively confirming their taxonomic affinities with the genus Perkinsus that are suggested collectively by their morphology, RFTM assay reactions, and in vitro cell-cycle characteristics. To narrow the taxonomic identifications of the Perkinsus sp. clam parasites isolated during this investigation, copies of the ITS regions of replicate rRNA gene complexes were PCR- amplified and sequenced. Although nucleotide sequences of genes encoding functional rRNAs are highly conserved evolutionarily, ITS sequences can vary significantly between related taxa and are often useful for differentiating closely related species (Goggin 1994).

Four variant forms ( $a$ to $d$ ) of the ITS-region sequences were obtained from each of the 2 clonal 
Fig. 9. Maximum parsimony tree with bootstrap support values (\% of 1000 replicates), showing taxonomic affinities of Perkinsus sp. isolates from Mya arenaria (ATCC 50864) and Tagelus plebeius (ATCC 50866) with described Perkinsus sp. mollusc parasites, based on rRNA gene complex ITS-region nucleotide sequences. Four distinct sequence types $(a, b$, $c$, and $d$ ) were amplified from each monoclonal isolate, and sequences of each type were similar between isolates. Our isolates from clams were similarly polymorphic at the sequenced loci, were monophyletic with both $P$. chesapeaki and $P$. andrewsi, and were clearly differentiated from other described Perkinsus species. GenBank accession numbers for sequences used in the analyses are given in parentheses

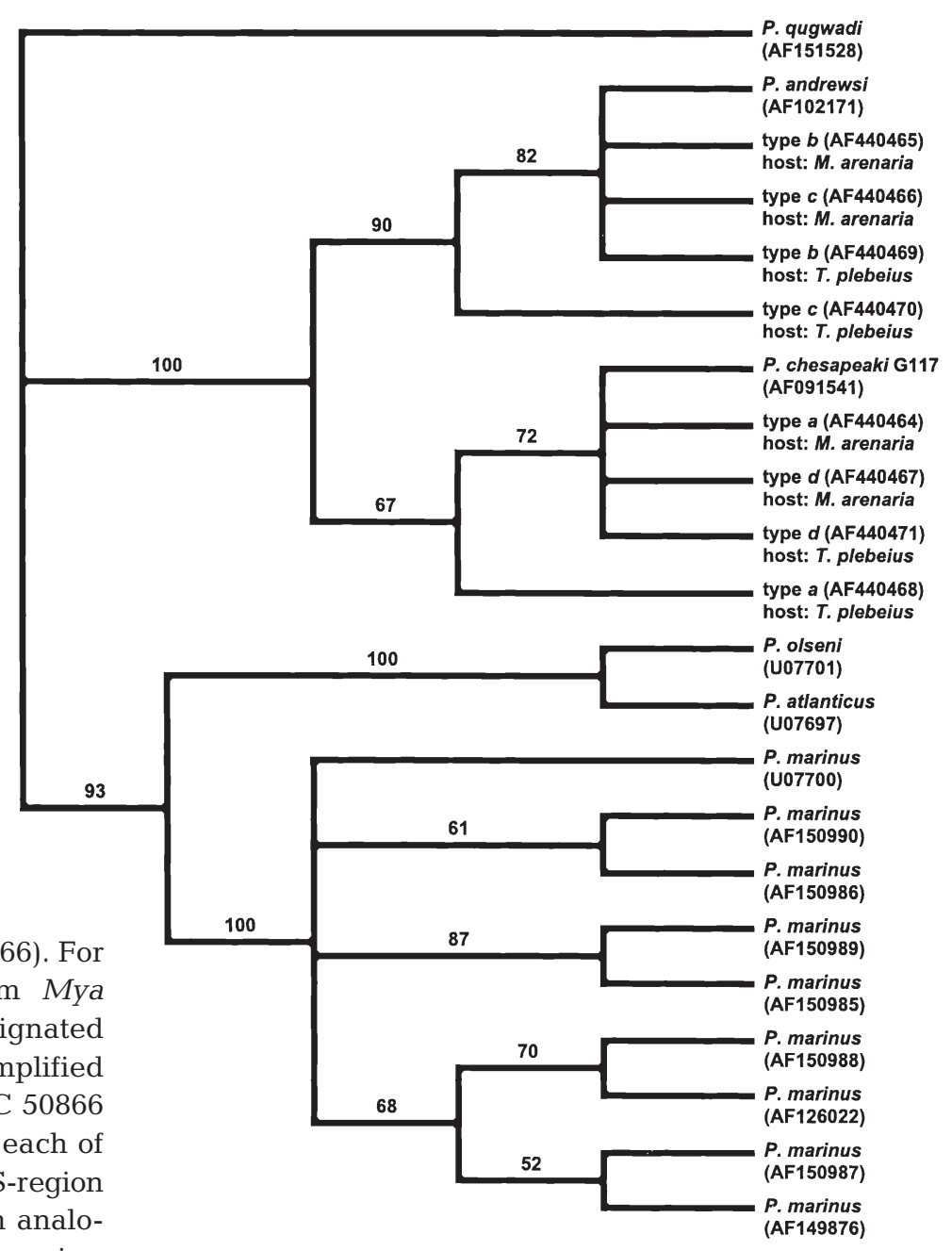

wise sequence distances among $P$. chesapeaki and the $a$ - and $d$-type sequences ranged from 0.3 to $1.2 \%$. Pairwise distances among $P$. andrewsi and the $b$ - and $c$ type sequences ranged from 0.4 to $2.1 \%$. Overall pairwise distances ranged from 0.3 to $4.0 \%$ among the $P$. chesapeaki/P. andrewsi/a-, $b$-, $c$-, and $d$-type ITS sequence group.

\section{DISCUSSION}

Two significant diseases appear to have emerged in recent years among Chesapeake Bay clams. During 1969 to 1978, disseminated neoplasia in Chesapeake Bay Mya arenaria was absent in 362 clams collected from the same tributaries sampled during the present study. However, DN disease was detected in softshell clams from many of these same locations, and at epizootic prevalences up to $57 \%$, during 1983 and 1984 (Farley et al. 1986). Results of subsequent surveys conducted during 1984 to 1988 showed consistent 
epizootic DN disease in many sampled $M$. arenaria populations at prevalences up to $76 \%$, and positively correlated DN disease prevalences with clam mortality estimates (Farley et al. 1991). The results of the present study show that DN disease remains prevalent among Chesapeake Bay $M$. arenaria at levels which suggest it to be a cause of significant current softshell-clam mortalities. Maximum DN-disease prevalences of 33 and $37 \%$, recorded during the present study in samples from Eastern Bay, approximate mean prevalences recorded during 1985 to 1988 for clams in this region, and are below maximum prevalences of $58 \%$ recorded during those years. However, relatively moderate prevalences of a fatal neoplastic condition of unidentified etiology are alarming, and presage significant DN-disease mortalities among affected clam populations.

Softshell clam-disease mortalities may now be compounded by apparent new and prevalent infections by Perkinsus sp. pathogens, which, despite their conspicuous lesions, have only been detected histologically since 1990. All Mya arenaria and Tagelus plebeius samples tested during the current investigation showed high prevalences of Perkinsus sp. infections at intensities which suggest fatal outcomes.

In general, the in vitro cell cycles and morphological characteristics of our Perkinsus sp. isolates from both clam hosts are consistent with those reported for other isolates from clams, including an undescribed isolate from Macoma balthica (Kleinschuster et al. 1994), P. chesapeaki from Mya arenaria (McLaughlin et al. 2000), P. andrewsi from M. balthica (Coss et al. 2001b), and P. atlanticus from Tapes decussatus (Casas et al. 2002). Unlike $P$. marinus, which zoosporulates infrequently and only during its first in vitro generation after isolation from infected oyster tissues (La Peyre 1996), Perkinsus species isolated from clam hosts undergo persistent and frequent zoosporulation when propagated in vitro by methods similar or identical to those used with $P$. marinus. Of unknown relevance is the fact that zoospores of $P$. chesapeaki and $P$. andrewsi are described as oblong and ovoid, respectively (McLaughlin et al. 2000, Coss et al. 2001a), while those of $P$. marinus and of our clam isolates described here are pyriform. Persistent and continuous in vitro zoosporulation of parasite cultures isolated from both Mya arenaria and Tagelus plebeius clearly differentiate these isolates from the oyster pathogen P. marinus, but morphological and cell-cycle characteristics described to date for Perkinsus sp. isolates from clams do not appear to differentiate these isolates from each other.

Replicate DNA clones of ITS sequences amplified from clonal cells originally isolated and propagated from both Mya arenaria and Tagelus plebius grouped both isolates in 2 monophyletic sister clades. One clade included Perkinsus chesapeaki (Kotob et al. 1999a) ITS sequences, and the sister clade included $P$. andrewsi (Coss et al. 2001b) ITS sequences. This suggests that variation observed among the ITS sequences from our clam Perkinsus sp. isolates is representative of true polymorphism within a single parasite species that we isolated from 2 different hosts. Previous studies have indicated that $P$. marinus cultured cells are diploid (Reece et al. 1997). Assuming clonality and diploidy of the Perkinsus sp. isolates from our clams, the results presented here suggest variation among different chromosomal copies of ITS sequences, or between duplicate, tandemly-repeated rRNA gene copies on a single chromosome. Variability in ITS sequences from a single species has been observed in $P$. marinus (Brown 2001, Reece et al. 2001) and other protistan taxa (Adachi et al. 1995, James et al. 1996, Adam et al. 2000, Giacobbe et al. 2000). Further investigation is now needed to resolve whether the previously reported $P$. chesapeaki and $P$. andrewsi ITS sequences represent variant forms of ITS sequences from a single Perkinsus species whose inherent ITS-region polymorphisms may have gone undetected in previous studies.

Identification of Perkinsus sp. parasites isolated during this investigation as members of a P. chesapeaki/ $P$. andrewsi group implies that this pathogen group has widespread involvement in prevalent clam infections diagnosed during this study by RFTM assays, but from which confirmatory parasite isolations were not made. Both host and geographic ranges of $P$. chesapeaki/ $P$. andrewsi-group parasites appear to overlap, in part, those of $P$. marinus. Resolution of their disease effects on mollusc populations within their endemic areas will require robust parasitedifferentiation criteria, and development of speciesspecific diagnostic tools. Since P. chesapeaki infections in Mya arenaria appear to be either a recent phenomenon, or one whose distribution and prevalence have increased dramatically during the past $10 \mathrm{yr}$, pressing questions include whether $P$. chesapeaki is an introduced exotic pathogen, an endemic parasite expanding its host or regional distribution, or an avirulent endemic parasite whose infectivity and virulence have recently changed.

Historically, presumptive identification of Perkinsus sp. parasites has been based on parasitized host species and an increasingly challenged assumption of narrow parasite host-specificity. Although neither ubiquitous RFTM in vitro diagnostic assays nor existing in situ histological methods identify Perkinsus parasites to species, cell cycle characteristics of proliferating in vitro isolates differentiate $P$. marinus from both $P$. chesapeaki and $P$. andrewsi. Molecular genetic analyses of 
DNA nucleotide sequences may reliably differentiate species within the limitations of the growing nascent DNA nucleotide-sequence database available for such protozoans, and of current views on levels of sequence variation that reliably differentiate protozoan parasites. As our data show, apparent polymorphic rRNA gene complex ITS-region nucleotide sequences collectively align both of our isolates with both $P$. chesapeaki and $P$. andrewsi, indicating that sequences from such loci do not reliably differentiate these parasite species, if in fact they are taxonomically distinct.

The oyster pathogen Perkinsus marinus can also apparently infect Mya arenaria (McLaughlin \& Faisal 1998b, Kotob et al. 1999a), which may then theoretically serve as a reservoir or alternate host from which this pathogen can be transmitted back to oysters. Neither the infectivity of $P$. chesapeaki for oysters nor the oyster disease and mortality consequences of such putative infections are known. P. andrewsi, isolated and described from the clam Macoma balthica, was shown by PCR assays to also infect oysters and at least 2 other (non- $M$. arenaria) sympatric Chesapeake Bay clam hosts. P. marinus was also detected by PCR assays in all of the same clam host species, and simultaneously with $P$. andrewsi in many individual clams, but no estimates of specific virulence or pathology of either parasite in any host are given (Coss et al. 2001b). Since current quantitative and in situ diagnostic assays do not distinguish $P$. marinus, $P$. chesapeaki, and P. andrewsi, the specific infectivities and virulences of these parasites for several Chesapeake Bay clams, and those of $P$. chesapeaki and $P$. andrewsi for sympatric oysters, remain to be determined.

Despite repeated, unsubstantiated assertions that Perkinsus marinus and $P$. chesapeaki may concomitantly co-infect the same Mya arenaria host clam (Kotob et al. 1999a,b), data demonstrating putative dual infections in the same clam have never been presented. Apparent dual infections by multiple Perkinsus spp. parasites were detected by PCR assays in both oysters and clams (Coss et al. 2001a), but confirmatory in situ differentiation and localization of the several implicated parasite species were not performed. Resolution of specific impacts on clam and oyster mortalities by the growing number of Perkinsus species known to infect Chesapeake Bay molluscs requires quantitative parasite differentiation and enumeration in host mollusc tissues and environmental samples. However, development of parasite-specific diagnostic tools and reagents, such as antibodies, nucleic acid probes, and PCR assays demands a comprehensive understanding of the full range of parasite diversity to be discriminated, to guide discovery of objective criteria for differentiating members of valid, extant pathogen taxa.
Acknowledgements This report presents partial results of a clam survey conducted jointly by the Maryland DNR Fisheries Service, Shellfish and Cooperative Oxford Laboratory programs. We thank Shellfish Program staff Dr. Mark Homer and Robert Bussell for field sampling that provided clams and data for disease analyses, and Mitchell Tarnowski also for a thorough and constructive manuscript review. We thank Cooperative Oxford Laboratory histotechnicians Charles Gieseker, Judson Blazek, and Suzanne Tyler for processing clam tissues and reading RFTM assays, pathologist Sara Otto for reading histological assays, and Kelly Greenhawk for mapping sampling stations. This work was funded in part by USDOC/NOAA award NA17FU1652 from the Chesapeake Bay Stocck Assessment Committee and award VA-OD0104 from the Sea Grant Oyster Disease Research Program. This manuscript is VIMS contribution 2437.

\section{LITERATURE CITED}

Adachi M, Sako Y, Uchida A, Ishida Y (1995) Ribosomal DNA internal transcribed spacer regions (ITS) define species of the genus Alexandrium. In: Harmful algal blooms. Proc 6th Int Conf Toxic Marine Phytoplankton, October 1993, Nantes, p 15-20

Adam RD, Ortega YR, Gilman RH, Sterling CR (2000) Intervening transcribed spacer region 1 variability in Cyclospora cayetanensis. J Clin Microbiol 38:2339-2343

Andrews JD (1954) Notes on fungus parasites of bivalve molluscs in Chesapeake Bay. Proc Natl Shellfish Assoc 45:157-163

Blackbourn J, Bower SM, Meyer GR (1998) Perkinsus qugwadi sp. nov. (Incertae sedis), a pathogenic protozoan parasite of Japanese scallops, Patinopecten yessoensis, cultured in British Colombia, Canada. Can J Zool 76:942-953

Brown GD (2001) Molecular characterization of Perkinsus marinus isolates. PhD thesis, The College of William and Mary, Williamsburg, VA

Brown RS, Wolke RE, Saila SB, Brown CW (1977) Prevalence of neoplasia in ten New England populations of the softshell clam (Mya arenaria). Ann NY Acad Sci 298:522-534

Bushek D, Holley RA, Reece KS (2000) Use of micromanipulation and 'feeder layers' to clone the oyster pathogen Perkinsus marinus. J Eukaryot Microbiol 47:164-166

Bushek D, Dungan CF, Lewitus AJ (2002) Serological affinities of the oyster pathogen Perkinsus marinus (Apicomplexa) with some dinoflagellates (Dinophyceae). J Eukaryot Microbiol 49:11-16

Casas SM, La Peyre JF, Reece KS, Azevedo C, Villalba A (2002) Continuous in vitro culture of the carpet shell clam Tapes decussatus protozoan parasite Perkinsus atlanticus. Dis Aquat Org (in press)

Choi KS, Wilson EA, Lewes DH, Powell EN, Ray SM (1989) The energetic cost of Perkinsus marinus parasitism in oysters: quantification of the fluid thioglycollate method. J Shellfish Res 8:125-131

Coss KA, Robledo JAF, Vasta GR (2001a) Fine structure of clonally propagated in vitro life stages of a Perkinsus sp. isolated from the Baltic clam Macoma balthica. J Eukaryot Microbiol 48:38-51

Coss KA, Robledo JAF, Ruiz GM, Vasta GR (2001b) Description of Perkinsus andrewsi n. sp. isolated from the Baltic clam (Macoma balthica) by characterization of the ribosomal RNA locus, and development of a speciesspecific PCR-based diagnostic assay. J Eukaryot Microbiol 48:52-61

Dungan CF, Hamilton RM (1995) Use of a tetrazolium-based 
cell proliferation assay to measure effects of in vitro conditions on Perkinsus marinus (Apicomplexa) proliferation. J Eukaryot Microbiol 42:379-388

Dungan CF, Roberson BS (1993) Binding specificities of mono- and polyclonal antibodies to the oyster pathogen Perkinsus marinus. Dis Aquat Org 15:9-22

Elston RA, Moore JD, Brooks K (1992) Disseminated neoplasia of bivalve molluscs. Rev Aquat Sci 6:405-466

Farley CA, Otto SV, Reinisch CL (1986) New occurrence of epizootic sarcoma in Chesapeake Bay soft shell clams, Mya arenaria. Fish Bull (Wash DC) 84:851-857

Farley CA, Plutschak DL, Scott RF (1991) Epizootiology and distribution of transmissible sarcoma in Maryland softshell clams, Mya arenaria, 1984-1988. Environ Health Perspect 90:35-41

Giacobbe MG, Penna A, Ceredi A, Melandri A, Poletti R, Yang A (2000) Toxicity and ribosomal DNA of the dinoflagellate Dinophysis sacculus (Dinophyta). Phycologia 39:60-65

Goggin CL (1994) Variation in the two internal transcribed spacers and 5.8S ribosomal RNA from five isolates of the marine parasite Perkinsus (Protista, Apicomplexan). Mol Biochem Parasitol 64:179-182

House ML, Kim CH, Reno PW (1998) Soft shell clams Mya arenaria with disseminated neoplasia demonstrate reverse transcriptase activity. Dis Aquat Org 34:187-192

James SA, Collins MD, Roberts IN (1996) Use of an rRNA internal transcribes spacer region to distinguish phylogenetically closely related species of the genera Zygosaccharomyces and Torulaspora. Int J Syst Bacteriol 46: 189-194

Kleinschuster SJ, Perkins FO, Dykstra MJ, Swink SL (1994) The in vitro life cycle of a Perkinsus species (Apicomplexa, Perkinsidae) isolated from Macoma balthica (Linneaus, 1758). J Shellfish Res 13:461-465

Kotob SI, McLaughlin SM, van Berkum P, Faisal M (1999a) Discrimination between two Perkinsus spp. isolated from the softshell clam, Mya arenaria, by sequence analysis of two internal transcribed spacer regions and the 5.8S ribosomal RNA gene. Parasitology 119:363-368

Kotob SI, McLaughlin SM, van Berkum P, Faisal M (1999b) Characterization of two Perkinsus spp. from the softshell clam, Mya arenaria using the small subunit ribosomal RNA gene. J Eukaryot Microbiol 46:439-444

La Peyre JF (1996) Propagation and in vitro studies of Perkinsus marinus. J Shellfish Res 15:89-101

La Peyre JF, Faisal M (1995) Improved method for the initiation of continuous cultures of the oyster pathogen Perkinsus marinus (Apicomplexa). Trans Am Fish Soc 124:144-146

Mackin JG (1961) Oyster disease caused by Dermocystidium marinum and other microorganisms in Louisiana. Publ Inst Mar Sci Univ Tex 7:133-229

McLaughlin SM, Faisal M (1998a) Histopathological alterations associated with Perkinsus spp. infection in the softshell clam Mya arenaria. Parasite 5:263-271

Editorial responsibility: Albert Sparks, Seattle, Washington, USA
McLaughlin SM, Faisal M (1998b) In vitro propagation of two Perkinsus species from the softshell clam Mya arenaria. Parasite 5:341-348

McLaughlin SM, Faisal M (1999) A comparison of diagnostic assays for detection of Perkinsus species in the softshell clam, Mya arenaria. Aquaculture 170:197-204

McLaughlin SM, Faisal M (2000) Prevalence of Perkinsus spp. in Chesapeake Bay soft-shell clams, Mya arenaria (Linnaeus 1758) during 1990-1998. J Shellfish Res 19:349-352

McLaughlin SM, Farley CA, Hetrick FM (1992) Transmission studies of sarcoma in the soft-shell clam, Mya arenaria. In Vivo (Attiki) 6:367-370

McLaughlin SM, Tall BD, Shaheen A, El Sayed EE, Faisal M (2000) Zoosporulation of a new Perkinsus species isolated from the gills of the softshell clam Mya arenaria. Parasite $7: 115-122$

Oprandy JJ, Chang PW, Pronovost AD, Cooper KR, Brown RS, Yates VJ (1981) Isolation of a viral agent causing hematopoietic neoplasia in the soft-shell clam, Mya arenaria. J Invertebr Pathol 38:45-51

Otto SV, Harshbarger JC, Chang SC (1979) Status of selected unicellular eukaryote pathogens, and prevalence and histopathology of inclusions containing obligate prokaryote parasites, in commercial bivalve mollusks from Maryland estuaries. Haliotis 8:285-295

Perkins FO (1996) The structure of Perkinsus marinus (Mackin, Owen, and Collier, 1950) Levine, 1978, with comments on taxonomy and phylogeny. J Shellfish Res $15: 67-88$

Peters EC (1988) Recent investigations on the disseminated sarcomas of marine bivalve molluscs. Am Fish Soc Spec Publ 18:74-92

Ray SM (1963) A review of the culture method for detecting Dermocystidium marinum, with suggested modifications and precautions. Proc Natl Shellfish Assoc 54:55-69

Reece KS, Bushek D, Graves JE (1997) Molecular markers for population genetic analysis of Perkinsus marinus. Mol Mar Biol Biotechnol 6:201-210

Reece KS, Brown GD, Hudson KL, Apakupakul K (2001) Inter- and intra-specific genetic variation among Perkinsus species: implications for species identification and development of molecular diagnostics. J Shellfish Res 20:554

Smolowitz RM, Miosky D, Reinisch CL (1989) Ontogeny of leukemic cells of the soft shell clam. J Invertebr Pathol 53:41-51

Sunila I, Farley CA (1989) Environmental limits for survival of sarcoma cells from the soft-shell clam Mya arenaria. Dis Aquat Org 7:111-115

Sunila I, Hamilton RM, Dungan CF (2001) Ultrastructural characteristics of the in vitro cell cycle of the protozoan pathogen of oysters, Perkinsus marinus. J Eukaryot Microbiol 48:348-361

Swofford DL (1999) PAUP: phylogenetic analysis using parsimony, Version 4.0. Sinauer Associates Publishers, Sunderland, MA

Submitted: August 2, 2001; Accepted: December 28, 2001

Proofs received from author(s): June 14, 2002 